\title{
IMPLEMENTASI MODEL PEMBELAJARAN TEAM-WORK DALAM MENINGKATKAN KEMAMPUAN MENANGKAP MAKNA TEKS PROSEDUR PESERTA DIDIK KELAS XII.MIPA.3 MADRASAH ALIYAH NEGERI 2 PONOROGO TAHUN PELAJARAN 2018/2019".
} Winarni Dwi Pratiwi

Guru Madrasah Aliyah Negeri 2 Ponorogo

\begin{abstract}
Abstrak
Kegiatan belajar pembelajaran salah satunya adalah proses transfer of knowledge dari guru kepada peserta didiknya. Implementasi pembelajaran bahasa Inggris menggunakan Kurikulum tahun 2013 menuntut beberapa perubahan yang mendasar. Pertama adalah pergeseran dari fokus pada guru (how to teach) ke fokus pada peserta didik (how to learn). Kedua adalah keberhasilan dalam menguasai bidang keilmuannya, bukan hanya sekedar pemahaman atau aspek pengetahuan saja melainkan disertai life skills (keterampilan) dasar yang ditandai dengan perubahan sikap pada prestasi belajar peserta didik yang meningkat. Rumusan masalah dalam penelitian ini adalah: Apakah model pembelajaran team work dapat meningkatkan kemampuan menangkap makna dalam teks prosedur lisan dan tulis berbentuk resep di kelas XII.MIPA.3 Madrasah Aliyah Negeri 2 Ponorogo Tahun Pelajaran 2018/2019. Dalam penelitian ini peneliti berkolaborasi dengan guru lain serta dengan kepala sekolah. Peneliti terlibat langsung dalam penelitian mulai dari awal sampai penelitian berakhir. Peneliti berusaha melihat, mengamati, merasakan, menghayati, merefleksi dan mengevaluasi kegiatan pembelajaran yang berlangsung. Tahap-tahap pelaksanaan penelitian tindakan terdiri dari perencanaan (planning), pelaksanaan (acting), observasi (obseving), dan refleksi (relecting). Untuk mendapatkan hasil penelitian yang akurat maka data yang telah terkumpul dianalisis secara statistik yaitu mengunakan rumus mean atau rata-rata. Criteria kesuksesan yang menandai berhasil tidaknya penelitian ini adalah KKM (Kriteria Ketuntasan Minimal) yaitu nilai 75 yang bisa dicapai oleh 80\% peserta didik. Dari hasil penelitian didapatkan bahwa nilai rata-rata pada siklus mengalami peningkatan yang signifikan. Mengacu pada hipotesis tindakan yang diajukan dalam penelitian tindakan kelas ini maka dapat disimpulkan bahwa : ada peningkatan kemampuan menangkap makna dalam teks prosedur lisan dan tulis berbentuk resep dengan model pembelajaran team work peserta didik kelas XII.MIPA.3 Madrasah Aliyah Negeri 2 Ponorogo Tahun Pelajaran 2018/2019.
\end{abstract}




\section{A. Pendahuluan}

Bahasa Inggris merupakan alat untuk berkomunikasi secara lisan dan tulis. Kemampuan berkomunikasi dalam pengertian yang utuh adalah kemampuan berwacana, yakni kemampuan memahami dan/atau menghasilkan teks lisan dan/atau tulis yang direalisasikan dalam empat keterampilan berbahasa, yaitu mendengarkan, berbicara, membaca dan menulis. Keempat keterampilan inilah yang digunakan untuk menanggapi atau menciptakan wacana dalam kehidupan bermasyarakat. Oleh karena itu, mata pelajaran Bahasa Inggris diarahkan untuk mengembangkan keterampilan-keterampilan tersebut agar lulusan mampu berkomunikasi dan berwacana dalam bahasa Inggris pada tingkat literasi tertentu.

Tingkat literasi mencakup performative, functional, informational, dan epistemic. Pada tingkat performative, orang mampu membaca, menulis, mendengarkan, dan berbicara dengan simbol-simbol yang digunakan. Pada tingkat functional, orang mampu menggunakan bahasa untuk memenuhi kebutuhan hidup sehari-hari seperti membaca surat kabar, manual atau petunjuk. Pada tingkat informational, orang mampu mengakses pengetahuan dengan kemampuan berbahasa, sedangkan pada tingkat epistemic orang mampu mengungkapkan pengetahuan ke dalam bahasa sasaran.

Suatu kenyataan bahwa pelajaran bahasa Inggris yang semestinya mata pelajaran yang menarik dan menyenangkan ternyata menjadi mata pelajaran yang menjadi momok bagi peserta didik-siswi saat ini. Salah satu penyebabnya adalah proses pembelajaran bahasa Inggris cenderung dihadapkan pada hal-hal yang tidak menarik.

Standar kompetensi mata pelajaran Bahasa Inggris merupakan kualifikasi kemampuan minimal peserta didik yang menggambarkan penguasaan pengetahuan, keterampilan berbahasa, dan sikap positif terhadap 
bahasa Inggris. Standar kompetensi ini merupakan dasar bagi peserta didik untuk memahami dan merespon situasi lokal, regional, nasional, dan global.

Dalam mencapai standar kompetensi tersebut ada beberapa ruang lingkup mata pelajaran Bahasa Inggris di SMA/MA yang harus terpenuhi, meliputi:

1. kemampuan berwacana, yakni kemampuan memahami dan/atau menghasilkan teks lisan dan/atau tulis yang direalisasikan dalam empat keterampilan berbahasa, yakni mendengarkan, berbicara, membaca dan menulis secara terpadu untuk mencapai tingkat literasi informational;

2. kemampuan memahami dan menciptakan berbagai teks fungsional pendek dan monolog serta esei berbentuk procedure, descriptive, recount, narrative, report, news item, analytical exposition, hortatory exposition, spoof, explanation, discussion, review, public speaking. Gradasi bahan ajar tampak dalam penggunaan kosa kata, tata bahasa, dan langkah-langkah retorika;

3. kompetensi pendukung, yakni kompetensi linguistik (menggunakan tata bahasa dan kosa kata, tata bunyi, tata tulis), kompetensi sosiokultural (menggunakan ungkapan dan tindak bahasa secara berterima dalam berbagai konteks komunikasi), kompetensi strategi (mengatasi masalah yang timbul dalam proses komunikasi dengan berbagai cara agar komunikasi tetap berlangsung), dan kompetensi pembentuk wacana (menggunakan piranti pembentuk wacana).

Berdasarkan pada penjelasan di atas, sangat menarik apabila dikaji dan dibahas penggunaan model pembelajaran team-work dalam meningkatkan kemampuan menangkap makna teks prosedur peserta didik kelas XII.MIPA.3 Madrasah Aliyah Negeri 2 Ponorogo Tahun Pelajaran 2018/2019”. Perlunya kajian ini menurut penulis akan mampu memenuhi standar kompetensi yang telah ditentukan. Selain itu penulis juga akan memberikan pandangan 
terhadap model pembelajaran team-work dalam meningkatkan kemampuan menangkap makna teks prosedur peserta didik kelas XII.MIPA.3 Madrasah Aliyah Negeri 2 Ponorogo Tahun Pelajaran 2018/2019.

\section{B. Pembelajaran Team-Work Dalam Meningkatkan Motivasi Belajar Peserta Didik}

Dalam pembelajaran Bahasa Inggris terdapat bebarapa kompetensi penting yang harus dimiliki. Pertama, Kompetensi Pembentuk Wacana (Discourse Competence). Kompetensi ini mengacu pada kemampuan menerapkan unsur-unsur berikut untuk menghasilkan teks-teks yang komponen-komponennya tersusun secara terpadu (koheren) antara lain karena adanya piranti kohesi (cohesive devices) sehingga tercapai teks yang koheren. Teks yang koheren adalah teks yang mencapai tujuan komunikatifnya karena komponennya disusun dengan baik dan setiap komponen direalisasikan dalam bahasa yang berterima. Kedua Kompetensi Kebahasaan (Linguistic competence). Kompetensi ini mengacu pada kemampuan menerapkan dan memahami unsur-unsur tatabahasa, kosakata, lafal, dan ejaan di dalam teks dengan benar. Ketiga Kompetensi Sosiokultural (Sociocultural Competence). Kompetensi ini mengacu pada kemampuan menyatakan pesan dengan benar dan berterima menurut konteks sosial budaya yang terkait dengan kegiatan komunikatif yang dilakukan. Keempat Kompetensi Strategi (Strategic Competence). Kompetensi ini mengacu pada kemampuan dan keterampilan menerapkan berbagai strategi berkomunikasi.

Untuk mencapai kompetensi pembelajaran yang baik, maka perlu penggunaan model yang tepat. Model yang dapat digunakan adalah Pembelajaran team work. Pembelajaran team work merupakan konsep belajar di mana guru mengelompokkan peserta didik menjadi kelompok dengan satu ketua kelompok. Sementara peserta didik memperoleh pengetahuan dan 
ketrampilan dari konteks yang terbatas, sedikit demi sedikit dari proses mengkonstruksi sendiri sampai pemecahan masalah kehidupan Nurhadi ( 2004 : 13 ). Pernyataan kunci dalam pembelajaran Pembelajaran Team work adalah:

1. Pembelajaran team work membantu guru mengaitkan konteks mata pelajran dengan dunia nyata dan memotivasi peserta didik membuat hubungan antara pengetahuan dan penerapan dalam kehidupan mereka.

2. Pembelajaran team work memungkinkan peserta didik, menguatkan memperluas dan menerapkan pengetahuan dan ketrampilan akademik mereka di lingkungannya, baik disekolah maupun luar sekolah.

3. Peserta didik belajar tidak dalam proses seketika, pengetahuan dan ketrampilan peserta didik diperoleh sedikit demi sedikit, berangkat dari pengetahuan yang dimiliki sebelumnya.

4. Kemajuan belajar peserta didik diukur dari proses kinerja dan produk, berbasis pada prinsip authentic assesment Nurhadi (2004 : 15)

Ide utamanya adalah untuk memotivasi peserta didik saling memberi semangat dengan membantu dalam menuntaskan ketrampilan- ketrampilan yang dipresentasikan guru. Jika peserta didik menginginkan tim mereka mendapatkan penghargaan tim, setiap anggota tim harus aktif terlibat dalam proses kerja tim. team work terdiri dari lima komponen utama; presentasi kelas, kerja tim, kuis, skor, dan penghargaan.

Dari uraian diatas dapat diketahui bahwa pembelajaran Bahasa Inggris tidak hanya di dominasi dengan suara, aktivitas dan pembicaraan guru semata. Padahal model pembelajaran ceramah merupakan sebagian kecil dari puluhan metode/strategi pembelajaran di kelas. Namun di samping itu pendekatan ini juga kurang disukai murid dan juga membosankan. Sehingga perlu usaha penggunan model pembelajaran Bahasa Inggris yang lebih disukai oleh peserta didik. Seperti penggunaan model pembelajaran team 
work. Dengan merubah model pembelajaran ini peserta didik lebih antusias dan termotivasi dalam belajar Bahasa Inggris. Motivasi muncul karena model pembelajaran yang lebih menarik.

\section{Pembelajaran Team-Work Dalam Meningkatkan Kemampuan Menangkap Makna Teks Prosedur Peserta Didik Kelas XII.MIPA.3 MAN 2 Ponorogo}

Seperti kurikulum mata pelajaran lainnya, Kurikulum Bahasa Inggris merupakan bagian dari Kurikulum 2013, yang ruang lingkup pengelolaannya dimulai dari merumuskan Kompetensi Dasar (KD), khususnya KD 3 dan KD 4, untuk mengejawantahkan KI 3 dan KI 4. Perumusan KD didasarkan pada beberapa asumsi tentang bahasa fungsional, termasuk konsep genre yang memberikan kerangka pembentukan teks yang terdiri atas tiga aspek: (1) tujuan atau fungsi sosial yang hendak dicapai, dengan menggunakan (2) struktur teks dan (3) unsur kebahasaan yang sesuai dengan tuntutan kontekstual.

Artinya, teks harus dipelajari sebagai alat untuk melaksanakan fungsi sosial secara kontekstual yang terkait langsung dengan kehidupan peserta didik sebagai remaja terpelajar dalam berinteraksi dengan lingkungan sekitarnya, secara lisan maupun tertulis. Kualitas teks dilihat dari kesesuaian struktur teks dan unsur kebahasaan dengan fungsi teks dalam konteks penggunaannya tersebut. Ketiga aspek genre inilah yang digunakan untuk menetapkan materi pembelajaran setiap jenis teks.

Pada jenjang SMA/MA/SMAK/MAK, pengetahuan faktual, konseptual, prosedural, dan metakognitif dipelajari pada tataran berpikir 'memahami' (khususnya mengidentifikasi, membandingkan, dan menafsirkan) dan tataran 'menerapkan'. Salah satu kompetensi dasar yang harus dikuasai oleh peserta didik di Madrasah Aliyah kelas XII.MIPA.3 adalah Menangkap makna secara 
kontekstual terkait fungsi sosial, struktur teks, dan unsur kebahasaan teks prosedur lisan dan tulis, dalam bentuk manual terkait penggunaan teknologi dan kiat-kiat (tips).

Untuk menguasai kompetensi dasar tersebut di atas, peneliti menggunakan team work dengan hipotesa awal bahwa model pembelajaran team work dapat meningkatkan kemampuan menangkap makna teks prosedur peserta didik kelas XII.MIPA.3 Madrasah Aliyah Negeri 2 Ponorogo. Dalam penelitian awal peneliti menemukan bahwa kemampuan menangkap makna teks prosedur peserta didik kelas XII.MIPA.3 Madrasah Aliyah Negeri 2 Ponorogo masih berkategori kurang dibuktikan dengan hasil dokumentasi nilai yang diperoleh peserta didik rata-rata 55\% yang mendapat nilai $>=75$.

Oleh karena itu peneliti merasa perlu menerapkan model pembelajaran team work sebagai upaya meningkatkan kemampuan menangkap makna teks prosedur pada peserta didik kelas XII.MIPA.3 Madrasah Aliyah Negeri 2 Ponorogo.

Untuk mengetahui perubahan tersebut dapat dibuktikan dari hasil belajar peserta didik dengan model pembelajaran team work melalui dua siklus. Pada siklus I, pelaksanaan kegiatan belajar mengajar dilaksanakan pada semester genap di kelas XII dengan jumlah peserta didik 32 peserta didik. Dalam hal ini peneliti bertindak sebagai guru. Adapun proses belajar mengajar mengacu pada rencana yang telah di persiapkan. Pengamatan (observasi) dilaksanakan bersamanaan dengan pelaksanaan belajar mengajar. Sebagai pengamat adalah guru bahasa Inggris di kelas XII.MIPA.3 Madrasah Aliyah Negeri 2 Ponorogo Tahun Pelajaran 2018/2019.

Pada akhir proses belajar mengajar peserta didik di beri tes formatif dengan tujuan untuk mengetahui tingkat keberhasilan peserta didik dalam proses belajar mengajar yang telah di lakukan. Ada aspek-aspek yang mendapatkan kriteria kurang baik yakni. memotifasi peserta didik, 
menyampaikan tujuan pembelajaran, pengelolaan waktu, dan sisawa antusias. Keempat aspek yang mendapat penilaian kurang baik. Ternyata prosentase ketuntasan lebih kecil dari yang dikehendaki yaitu sebesar 59,75\%, hal ini di sebabkan karena peserta didik masih merasa baru dan belum mengerti apa yang di maksudkan dan di gunakan guru dengan menerapkan pembelajaran team work.

Pada siklus II, pelaksanaan kegiatan belajar mengajar dilaksanakan seperti pada tahap pertama. Dari hasil yang diperoleh ketuntasan belajar mencapai $63.44 \%$. Hasil ini menunjukkan bahwa pada siklus II ini ketuntasan belajar secara klasikal telah mengalami peningkatan sedikit lebih baik dari siklus I. Adapun peningkatan hasil belajar peserta didik ini karena setelah guru menginformasikan bahwa setiap akhir pelajaran akan selalu diadakan tes sehingga pada pertemuan berikutnya peserta didik lebih termotivasi untuk belajar. Selain itu peserta didik juga sudah mulai mengerti apa yang di maksudkan dan diinginkan guru dengan menerapkan pembelajaran team work.

Hasil penelitian ini menunjukkan bahwa pembelajaran team work memiliki dampak positif dalam meningkatkan prestasi belajar peserta didik. Hal ini dapat dilihat dari semakin mantapnya pemahaman peserta didik terhadap materi yang disampaikan guru. Hal ini berdapak positif terhadap prestasi belajar peserta didik yaitu dapat di tunjukkan dengan meningkatnya nilai rata-rata peserta didik pada setiap tahap yang terus mengalami peningkatan.

Aktifitas peserta didik dalam proses pembelajaran Bahasa Inggris dengan model pembelajaran team work yang paling dominan adalah bekerja dengan menggunakan alat atau media, mendengarkan/memperhatikan penjelasan guru dan diskusi antar peserta didik dengan guru. Jadi dapat dikatakan bahwa aktifitas peserta didik dapat dikategorikan aktif. 
Sedangkan untuk aktifitas guru selama pembelajaran telah melaksanakan langkah-langkah pembelajaran team work dengan baik. Hal ini terlihat dari aktifitas guru yang muncul diantaranya aktifitas membimbing dan mengamati peserta didik dalam mengerjakan kegiatan worksheet/menemukan konsep dan lain-lain

\section{Penutup}

Berdasarkan hasil analisis data penelitian di kelas XII.MIPA.3 Madrasah Aliyah Negeri 2 Ponorogo Tahun Pelajaran 2018/2019 dengan menggunakan model pembelajaran team work prestasi belajar peserta didik dapat ditingkatkan. Model pembelajaran team work juga mampu menumbuhkan rasa percaya diri dan kerjasama dalam tim.

Sebagian besar waktu guru digunakan untuk membimbing peserta didik, mendorong dan melatihkan kemampuan kooperatif, sedangkan waktu terbanyak bagi peserta didik dalam mengerjakan Lembar Kerja (worksheet). Peserta didik dalam kelompok belajarnya (pembelajaran) adalah saling bekerjasama dalam kelompok untuk mengerjakan Lembar Kerja, diskusi antar peserta didik maupun antara peserta didik dengan guru terjadi dengan cukup intensif, sehingga dapat dikatakan peserta didik lebih antusias dalam mengikuti pembelajaran.

Melalui pembelajaran team work ini peserta didik mampu mengembangkan kreativitas mereka dalam mentransfer materi di antara anggota kelompok belajarnya, sehingga mereka lebih senang dan aktif belajar di dalam kelompok belajarnya. Model pembelajaran team work cukup efektif diterapkan dalam pembelajaran karena mayoritas kelompok belajar berhasil menuntaskan pemahaman materi yang diberikan,. Dan pemahaman konsep yang diterima lebih cepat merata bagi peserta didik. 


\section{Daftar Pustaka}

Bagod Sudjadi, 2004. Cooperative Learning. LPMP Jawa Timur

Hakim, L. 1996. Metodologi Penelitian. Malang: Universitas Negeri Malang.

Krisnani, Yiyis. English for vocational schools. Yogyakarta : LP2IP

Moleong, L.J. 2000. Metodologi Penelitian Kualiatif. Bandung: PT. Remaja Roskarya.

Prayitno, E. 1989. Motivasi dalam Belajar. DEPDIKBUD: Jakarta.

Purwanto, M.N. 1990. Psikologi Pendidikan. Bandung: PT. Remaja Roskadkarya.

Robert E. Slavin dalam Bagod Sudjadi, 2004. Cooperative Learning. LPMP Jawa Timur.

Sardiman. 1986. Interaksi dan Motivasi Belajar Mengajar Panduan Bagi Guru dan Peserta didik. Jakarta: Rajawali.

Tim Pengembang Balitbang. 2001. Kurikulum Bebasis Konpetensi Mata Pelajaran Bahasa Inggris Sekolah Menengah Atas. Jakarta: Departemen Pendidikan Nasional. 